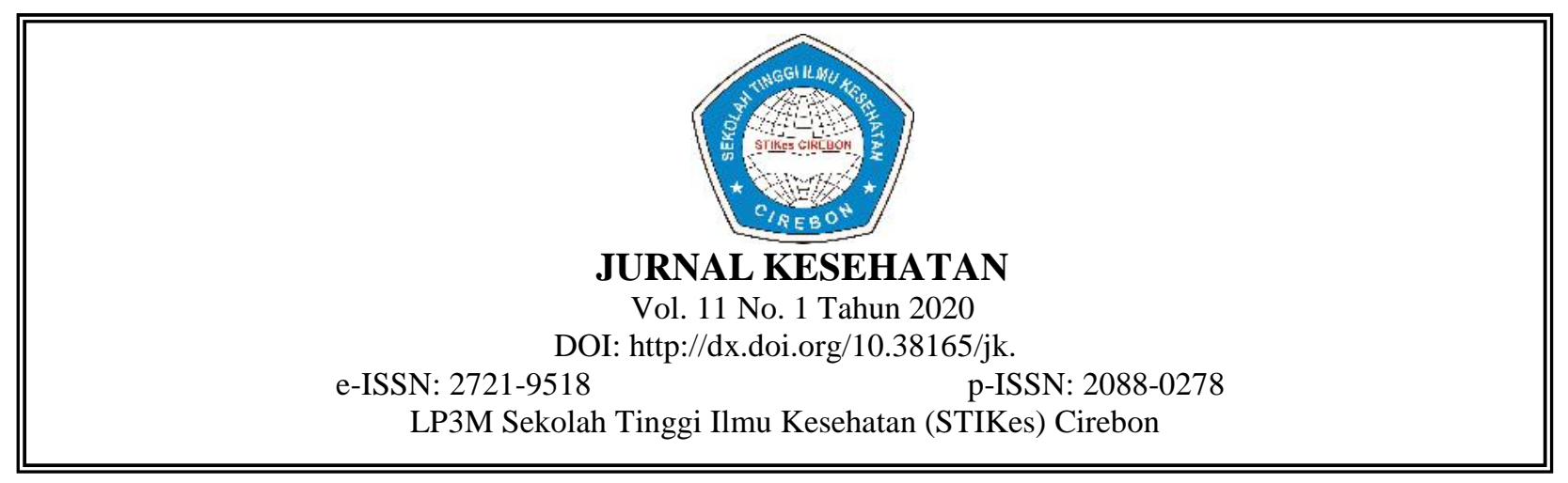

\title{
HUBUNGAN STATUS GIZI DENGAN MENSTRUASI DINI
}

\author{
Tutin Marlia* \\ Akademi Keperawatan Saifuddin Zuhri \\ marliatutin@yahoo.com
}

\begin{abstract}
Abstrak
Menarche merupakan menstruasi pertama yang biasa terjadi pada seorang gadis pada masa pubertas, yang biasanya muncul usia 11 sampai 14 tahun.Banyak hal yang mempengaruhi menarche pada remaja putri, antara lain adanya perubahan hormon yang mempengaruhi kematangan sel dan asupan gizi yang dikonsumsi saat menjelang datangnya menarche. Akhir-akhir ini, remaja putri sering mengalami menstruasi dini, dimana usia rata-rata saat menstruasi dimulai adalah antara 12-13 tahun, tetapi pada sebagian kecil remaja putri yang tampak normal,menarche mungkin muncul pada usia sedini 10 tahun atau selambat 16 tahun. Tujuan penelitian ini adalah untuk mengetahui Hubungan Status Gizi dengan Menstruasi Dini.

Jenis Penelitian yang digunakan dalam penelitian ini adalah kuantitatif dengan desain survei analitik dengan menggunakan rancangan cross sectional. Populasi dalam penelitian ini adalah siswi SMPN II Indramayu yang berjumlah 137 orang, teknik pengambilan sampel dalam penelitian ini menggunakan sampel random sampling secara acak sistematis dengan kriteria inklusi siswa yang sudah menstruasi yaitu sejumlah 97 orang. Tehnik analisa data menggunakan uji Chi Square.

Hasil penelitian ini adalah terdapat hubungan yang signifikan antara status gizi responden dengan menstruasi dini dengan nilai $P$ value 0.003 .
\end{abstract}

Kata Kunci: Status Gizi, Menstruasi Dini

\begin{abstract}
Menarche is the first menstruation that usually occurs in a girl at puberty, which usually appears at aged 11 to 14 years old. Many things affect menarche in young women, including hormonal changes that affect cell maturity and nutritional intake consumed just before the arrival of menarche. Lately, young women often experience early menstruation, where the average age when menstruation begins is between 12-13 years old, but in a small proportion of adolescent girls who appear normal, menarche may appear as early as 10 years old or as late as 16 years old. The purpose of this study was to determine the Relationship of Nutrition Status and Early Menstruation.

This type of research used in this research is quantitative with analytic survey design using cross sectional design. The population in this study were 137 students of SMPN II Indramayu, the sampling technique in this study used systematic random random sampling with the inclusion criteria of 97 menstruating students. Data analysis techniques using the Chi Square test

The results of this study show that there is a significant relationship between the nutritional status of respondents with early menstruation with the $P$ value of 0.003 .
\end{abstract}

Keywords: Nutrition Status, Early Menstruation 


\section{PENDAHULUAN}

Setiap satu diantara enam penduduk dunia adalah remaja.Sedangkan $85 \%$ diantaranya hidup di negara berkembang. Di Indonesia, jumlah remaja dan kaum muda berkembang sangat cepat. Pada tahun 2000, kelompok umur 15-24 tahun jumlahnya meningkat dari 21 juta menjadi 43 juta atau dari $18 \%$ menjadi $21 \%$ dari jumlah total populasi di Indonesia. Menurut World Health Organization (WHO) periode usia remaja yaitu antara 10-19 tahun. ${ }^{1}$

Masa remaja merupakan masa perubahan antara masa kanak-kanak dan masa dewasa yang meliputi perubahan biologik, perubahan psikologik dan perubahan sosial. Sebagian besar masyarakat dan budaya masa remaja pada umumnya dimulai pada usia 11 sampai dengan 13 tahun dan berakhir pada usia 18-22 tahun. Masa remaja diawali dengan pertumbuhan yang sangat cepat dan biasanyadisebut pubertas. ${ }^{2}$

Pubertas berlangsung kurang lebih selama 4 tahun. Pubertas dapat dimulai dengan awal berfungsinya ovarium, dan akan berakhir pada saat ovarium sudah berfungsi dengan mantap dan teratur. Kejadian penting pada pubertas ialah pertumbuhan badan yang cepat, timbulnya ciri kelamin sekunder, menarche, dan perubahan psikis. ${ }^{3}$

Menarche merupakan menstruasi pertama yang biasa terjadi pada seorang gadis pada masa pubertas, yang biasanya muncul usia 11 sampai 14 tahun. Perubahan penting terjadi pada masa gadis menjadi matang jiwa dan raganya melalui masa wanita dewasa. Hal ini menandakan bahwa anak tersebut sudah memasuki tahap kematangan organ seksual dalam tubuhnya. ${ }^{4}$

Banyak hal yang mempengaruhi menarche pada remaja putri, antara lain adanya perubahan hormon yang mempengaruhi kematangan sel dan asupan gizi yang dikonsumsi saat menjelang datangnya menarche. Asupan gizi yang kurang menyebabkan gizi pada seseorang akan berdampak pada penurunan fungsi reproduksi. Remaja yang memiliki riwayat menarche yang terlalu dini juga menyebabkan remaja tersebut terpapar hormon esterogen yang lebih lama dibandingkan dengan remaja yang menarchenya normal.

Akhir-akhir ini, remaja putri sering mengalami menstruasi dini, dimana usia rata-rata saat menstruasi dimulai adalah antara 12-13 tahun, tetapi pada sebagian kecil remaja putri yang tampak normal, menarche mungkin muncul pada usia sedini 10 tahun atau selambat 16 tahun. Masalah yang sering terjadi pada remaja adalah kurangnya asupan gizi yang mengakibatkan menderita kurang gizi yaitu terlalu kurus (Kurang Energi Kronik) dan dapat terkena anemia karena kekurangan zat besi, disamping itu masalah sering muncul adalah kelebihan asupan gizi yang dapat menyebabkan obesitas. Hal-hal tersebut sangat mempengaruhi keadaan tubuh dan sistem produksi hormon yang berkaitan erat dengan terjadinya menarche. ${ }^{5}$

Dari beberapa penelitian sejak 100 tahun terakhir menunjukkan bahwa ada kecenderungan semakin cepatnya remaja mengalami menstruasi. Pada tahun 1860 rata-rata usia remaja mengalami menstruasi adalah 16 tahun 8 bulan dan pada tahun 1975 umur 12 tahun 3 bulan. Adanya penurunan umur menstruasi tersebut disebabkan karena adanya perbaikan gizi,perbaikan pelayanan kesehatan dan lingkungan masyarakat. Semakin cepat seseorang mengalami menstruasi tentu semakin cepat pula ia memasukimasa reproduksi .Menstruasi sangat erathubungannya dengan masa puncak kurva kecepatanpenambahan tinggi badan.Masa ini ditentukan olehberbagai faktor, salah satunya adalah status gizi. ${ }^{6}$

Status gizi remaja wanita sangat mempengaruhi terjadinya menstruasi, adanya keluhankeluhan selama menarche maupun lamanya hari menarche, secara psikologi wanita remaja yang pertama kali mengalami haid akan mengeluh rasa nyeri, kurang nyaman, tetapi pada beberapa remaja keluhan-keluhan tersebut tidak dirasakan,hal ini dipengaruhi oleh nutrisi yang adekuat. ${ }^{7}$

Hasil RISKESDAS Indonesia tahun 2012 menunjukkan bahwa rata rata usia menarche di Indonesia adalah 13 tahun, dengan kejadian lebih awal pada usia kurang dari 9 tahun atau lebih lambat sampai usia 17 tahun. Di Jawa Timur, khususnya kota Surabaya, sekitar $0,1 \%$ remaja putri mengalami menarche lebih awal pada usia 6 sampai 8 tahun, dan sekitar 26,3\% lainnya mendapat menarche pada usia lebih dari 14 tahun. $^{8}$

Beberapa penelitian mengungkapkan faktor gizi termasuk faktor utama dalam percepatan usia menarche. Anak yang overweight/obese lebih cepat mengalami menarche dibandingkan 
dengan anak yang mempunyai berat badan normal. Penelitian dengan desain cross-sectional yang dilakukan di Kuwait menemukan berat badan anak yang normal merupakan faktor protektif terhadap kejadian menarche (OR: 0,84; $95 \%$ confidence interval (CI): $0,77-0,93) .{ }^{9}$ Penelitian kohort yang dilakukan di Inggris menemukan berat badan anak pada tinggi badan yang sama berhubungan terbalik dengan usia menarche. ${ }^{10}$

Usia untuk mencapai fase terjadinya menarche dipengaruhi oleh banyak faktor antara lain faktor suku, genetik, sosial, sekonomi, dan lain-lain. Di Inggris usia rata-rata untuk mencapai menstruasi adalah 13,1 tahun, sedangkan suku Bunding di Papua, menarche dicapai pada usia 18,8 tahun. ${ }^{11}$ Di Indonesia gadis remaja pada waktu menstruasi dini bervariasi antara 10-16 tahun dan rata-rata menarche 12,5 tahun, usia menstruasi dini di daerah perkotaan dari pada yang tinggal di desa dan juga lebih lambat wanita yang kerja berat. ${ }^{6}$

Penelitian ini akan dilakukan di SMPN II Indramayu. SMPN II Indramayu adalah salah satu sekolah menengah pertama negeri yang ada di wilayah Kecamatan Indramayu, Kabupaten Indramayu. Berdasarkan studi pendahuluan yang dilakukan oleh peneliti dengan cara wawancara kepada 10 orang siswi, 3 diantaranya menstruasi pada umur 12 tahun, 4 siswi menstruasi pada umur 10 tahun dan 3 siswi menstruasi pada umur 11 tahun. Di sekolah ini belum pernah dilakukan pengukuran status gizi.

\section{METODE PENELITIAN}

Jenis Penelitian yang digunakan dalam penelitian ini adalah kuantitatif dengan desain survei analitik dengan menggunakan rancangan cross sectional. Populasi dalam penelitian ini adalah siswi SMPN II Indramayu yang berjumlah 137 orang, teknik pengambilan sampel dalam penelitian ini menggunakan sampel random sampling secara acak sistematis dengan kriteria inklusi siswa yang sudah menstruasi yaitu sejumlah 97 orang. Sumber data yang digunakan adalah primer berupa data langsung dari responden dan data sekunder berupa informasi tentang profil dan jumlah siswa. Instrumen pengumpulan data berupa lembar observasi pengukuran tinggi badan dan berat badan dengan menggunakan alat ukur penimbang berat badan dan pengukur tinggi badan, kuisioner berupa pertanyaan tertutup tentang waktu menstruasi pertama. Tehnik analisa data yang digunakan adalah univariat dan bivariat dengan menggunakan uji Kai Kuadrat (Chi Square).

\section{HASIL}

\section{Usia Responden}

Tabel 1.Distribusi Frekuensi Responden Berdasarkan Usia

\begin{tabular}{lcc}
\hline \multicolumn{1}{c}{ Usia Responden } & $\mathrm{n}$ & Presentase $(\%)$ \\
\hline 12 tahun & 15 & 15.5 \\
13 tahun & 62 & 63.9 \\
14 tahun & 20 & 20.6 \\
\hline Total & 97 & 100 \\
\hline
\end{tabular}

Berdasarkan tabel 1 dapat dijelaskan bahwa umur responden terbanyak adalah di usia 13 tahun yaitu 62 orang (63.9\%).

\section{Usia Menarche}

Tabel 2.Distribusi Frekuensi Responden Berdasarkan Usia Menarche

\begin{tabular}{lcc}
\hline \multicolumn{1}{c}{ Usia Menarche } & $\mathrm{n}$ & Presentase (\%) \\
\hline Menarche Dini & 44 & 45.4 \\
Tidak Menarche Dini & 53 & 54.6 \\
\hline Total & 97 & 100 \\
\hline
\end{tabular}


Berdasarkan tabel 2 dapat dijelaskan bahwa dari 97 responden terdapat 44 responden $(45.4 \%)$ yang mengalami menstruasi dini.

\section{Usia Menarche}

Tabel 3.Distribusi Frekuensi Responden Berdasarkan Status Gizi

\begin{tabular}{lcc}
\hline \multicolumn{1}{c}{ Usia Menarche } & $\mathrm{n}$ & Presentase $(\%)$ \\
\hline Kurus & 42 & 43.3 \\
Normal & 49 & 50.5 \\
Gemuk & 6 & 6.2 \\
\hline Total & 97 & 100 \\
\hline
\end{tabular}

Berdasarkan tabel 3 dapat dijelaskan bahwa status gizi responden terbanyak adalah normal yaitu 49 responden $(50.5 \%)$ dan yang paling sedikit memiliki status gizi gemuk sejumlah 6 responden $(6.2 \%)$.

\section{Hubungan Antara Status Gizi Dengan Menstruasi Dini}

Tabel 4. Hubungan Antara Status Gizi Dengan Menstruasi Dini

\begin{tabular}{|c|c|c|c|c|c|c|c|}
\hline \multirow[t]{3}{*}{ Status Gizi } & \multicolumn{4}{|c|}{ Penanganan Dismenore } & \multicolumn{2}{|c|}{ Total } & \multirow[t]{3}{*}{ Nilai $p$} \\
\hline & \multicolumn{2}{|c|}{ Menstruasi Dini } & \multicolumn{2}{|c|}{ Tidak Menstruasi Dini } & \multirow[t]{2}{*}{$\mathrm{n}$} & \multirow[t]{2}{*}{$\%$} & \\
\hline & $\mathrm{n}$ & $\%$ & $\mathrm{n}$ & $\%$ & & & \\
\hline Kurus & 13 & 29.55 & 29 & 54.72 & 42 & 45.36 & 0.003 \\
\hline Normal & 25 & 56.81 & 24 & 45.28 & 49 & 52.57 & \\
\hline Gemuk & 6 & 13.63 & 0 & 0 & 6 & 2.06 & \\
\hline
\end{tabular}

Berdasarkan tabel 4 dapat dijelaskan bahwa responden yang memilki status gizi gemuk seluruhnya (100\%) mengalami menstruasi dini, sedangkan $56.81 \%$ responden yang memiliki status gizi normal mengalami menstruasi dini. Berdasarkan hasil hitung Chi Square didapatkan angka $p$ 0.003 yang berarti terdapat hubungan yang signifikan antara status gizi responden dengan menstruasi dini pada siswi SMPN II Indramayu.

\section{PEMBAHASAN}

Menarche terjadi pada periode pertengahan pubertas atau yang biasa terjadi 6 bulan setelah mencapai puncak percepatan pertumbuhan. ${ }^{12}$ Mestruasi adalah haid yang pertama terjadi yang merupakan ciri khas kedewasaan seorangwanita yang sehat dan tidak hamil. ${ }^{13}$.Usia menarche bervariasi dari rentang umur 10-16 tahun, akan tetapi usia menarche dapat dikatakan normal apabila terjadi pada usia 12-14 tahun. ${ }^{14}$ Menstruasi dini dalam penelitian ini adalah menstruasi yang terjadi pada usia kurang dari 12 tahun, dihasilkan data bahwa dari 97 responden terdapat 44 orang responden mengalami menstruasi dini (45.4\%). Membaiknya standar kehidupan berdampak pada penurunan usia menarche ke usia yang lebih muda (menarche dini). ${ }^{14}$ Kondisi menarche dini ini dikaitkan dengan pubertas prekoks yang terjadi pada anak di usia kurang dari 12 tahun. ${ }^{12}$

Status gizi remaja wanita sangat mempengaruhi terjadinya menstruasi baik dari faktor usia terjadinya menstruasi, adanya keluhan-keluhan selama menstruasi maupun lamanya hari menstruasi. Secara psikologis wanita remaja yang pertama sekali mengalami haid akan mengeluh rasa nyeri, kurang nyaman, dan mengeluh perutnya terasa begah atau tegang. Tetapi pada beberapa remaja keluhan-keluhan tersebut tidakdirasakan, hal ini dipengaruhi oleh nutrisi yang adekuat yang biasa dikonsumsi, selain olahraga yang teratur. ${ }^{7}$

Status gizi merupakan keseimbangan antara asupan makanan dengan kebutuhan zat gizi. Status gizi baik atau optimal terjadi bila tubuh memperoleh cukup zat-zat gizi yang digunakan secara efisien, sehingga memungkinkan pertumbuhan fisik, kemampuan kerja dan kesehatan secara umum padatingkat setinggi mungkin. Status gizi kurang terjadi bila tubuh memperoleh zat-zat gizi 
dalam jumlah berlebihan sehingga menimbulkan efek toksis atau membahayakan. Pada status gizi kurang maupunlebih terjadi gangguan gizi. ${ }^{4}$

Pada penelitian ini dari 97 responden menghasilkan bahwa responden yang memiliki status gizi gemuk seluruhnya mengalami menstruasi dini, yang memiliki status gizi ideal 56.8\% mengalami menstruasi dini, sedangkan responden yang status gizi kurus $29.55 \%$ mengalami menstruasi dini, hasi akhir penelitian ini membuktikan bahwa ada hubungan yang signifikan antara status gizi dengan menstruasi dini dengan nilai $p$ value 0.003 .

Adanya hubungan antara status gizi dengan menstruasi dini disebabkan karena hasil penelitian menunjukan bahwa remaja yang status gizinya lebih cenderung mengalami menstruasi dini dibanding remaja yang status gizinya kurang ataupun cukup. Hal ini sejalan dengan penelitian yang dilakukan bahwa ada hubungan asupan gizi dan status gizi dengan kejadian menstruasi dini. ${ }^{15}$ Sejalan juga dengan penelitian yang di lakukan bahwa menarche berhubungan dengan status gizi, asupan lemak, frekuensi mengkonsumsi Junk food dan aktivitas fisik. ${ }^{16}$

Hal ini didukung oleh teori yang dikemukakan bahwa terdapat jumlah tertentu lemak tubuh dengan mulai dan berlangsungnya menstruasi. ${ }^{2}$ Teori ini menekankan bahwa menarche terjadi pada berat badan tertentu dari pada usia tertentu pada seorang wanita, menstruasi yang datang lebih awal biasanya disebabkan oleh beberapa faktor lain, diantaranya, adalah berat badan berlebihan, aktivitas fisik dan genetik. Selain itu dipengaruhi oleh rangsangan-rangsangan kuat seperti film, buku-buku bacaan dan majalah orang dewasa yang dapat mempercepat menstruasi lebih dini.

Beberapa penelitian mengungkapkan factorgizi termasuk faktor utama dalam percepatan usia menarche. Anak yang overweight/obese lebih cepat mengalami menarche dibandingkan dengan anak yang mempunyai berat badan normal. Penelitian dengan desain cross-sectional yang dilakukan di Kuwait oleh Al-Awadhi menemukan berat badan anak yang normal merupakan factor protektif terhadap kejadian menarche (OR:0,84; 95\% confidence interval (CI): 0,77-0,93). Penelitian kohort yang dilakukan di Inggris menemukan berat badan anak pada tinggi badan yang sama berhubungan terbalik dengan usia menarche. ${ }^{10}$

Nutrisi mempengaruhi kematangan seksual pada gadis yang mendapat menstruasi pertama lebih dini,mereka cenderung lebih berat dan lebih tinggi pada saat menstruasi pertama dibandingkan dengan mereka yang belum menstruasi pada usia yang sama. Sebaliknya pada gadis yang menstruasinya terlambat, beratnya lebih ringan daripada yang sudah menstruasi pada usia yang sama, walaupun tinggi badan (TB) mereka sama. Pada umumnya, mereka menjadi matang lebih dini akan memiliki body mass index (indeks masa tubuh, IMT) yang lebih tinggi dan mereka yang matang terlambat memiliki IMT lebih kecil pada usia yang sama. ${ }^{11}$ Menstruasi pada awalnya terjadi secara tidak teratur sampai mencapai umur 18 tahun. Titik kritis ukuran antropometri pencetus menstruasi dini (menarche) adalah berat badan $40 \mathrm{~kg}$ dan tinggi badan $148 \mathrm{~cm}$. Menurut Swenne mengemukakan bahwa terdapat hubungan antara massa tubuh dengan kejadian menstruasi dini, begitu pula dengan BMI dengan usia menstruasi. ${ }^{2}$

Selain itu menarche dini berhubungan karena beberapa faktor yang meliputi keadaan gizi, genetik, konsumsi makanan, hormon, sosial ekonomi, keterpaparan media massa orang dewasa (pornografi), perilaku seksual dan gaya hidup. Usia menarche dini yang berhubungan dengan faktor gizi karena kematangan seksual dipengaruhi oleh nutrisi dalam tubuh remaja. Remaja yang lebih dini menarche akan memiliki indeks masa tubuh (IMT) yang lebih tinggi dan remaja menarche terlambat memiliki IMT lebih kecil pada usia yang sama. ${ }^{17}$ Faktor genetik berperan mempengaruhi percepatan dan perlambatan menarche yaitu antara usia menarche ibu dengan usia menarche putrinya. ${ }^{18}$

\section{SIMPULAN}

1. Diketahui usia responden terbanyak adalah 13 tahun yaitu $63.9 \%$, usia 14 tahun $20.6 \%$ dan usia 12 tahun $15.5 \%$.

2. Diketahui responden yang mengalami menstruasi dini sebanyak $45.5 \%$ dan yang tidak mengalami menstruasi dini sebanyak 54.6\%. 
3. Diketahui status gizi responden dari 97 yang diteliti diantaranya yang memiliki status gizi kurus pada responden sebanyak $43.3 \%$, normal $50.5 \%$ dan gemuk $6.2 \%$, mayoritas responden memiliki status gizi normal

4. Diketahui dari responden dengan status gizi gemuk seluruhnya mengalami menstruasi dini, responden dengan status gizi kurus $29,55 \%$ mengalami menstruasi dini sedangkan $56.81 \%$ responden yang memiliki status gizi normal mengalami menstruasi dini.

5. Hasil penelitian menunjukan bahwa terdapat hubungan yang signifikan antara status gizi dengan menstruasi dini yang dapat dilihat dari hasil analisis bivariat berdasarkan hasil uji chi square dengan nilai $P$ value 0.003 .

\section{SARAN}

1. Bagi sekolah, Usaha Kesehatan Sekolah (UKS) perlu melakukan penilaian status gizi secara berkala kepada siswa guna mendeteksi adanya permasalahan-permasalahan gizi yang dapat berdampak terhadap kesehatan khususnya kesehatan reproduksi.

2. Bagi responden, status gizi dapat berpengaruh terhadap kondisi kesehatan reproduksi sehingga perlu adanya pemantauan asupan gizi yang dilakukan oleh siswa sendiri, sehingga yang diharapkan adalah gizi ideal atau normal.

3. Bagi peneliti selanjutnya, penelitian ini masih sangat terbatas karena hanya mengukur satu variabel saja, masih banyak variabel yang lain untuk diukur seperti faktor genetik, aktivitas fisik, junk food dan lain-lain yang dapat dihubungkan dengan kejadian menstruasi dini, sehingga peneliti lain dapat menindaklanjuti apa yang sudah peneliti lakukan sehingga dapat menghasilkan penelitian yang lebih sempurna.

\section{DAFTAR PUSTAKA}

1. Kusmiran E. Reproduksi remaja dan wanita. Jakarta: Salemba Medika; 2011

2. Waryana. Gizi reproduksi. Yogyakarta:Pustaka Rihama; 2010

3. Prawirohardjo, Sarwono. Ilmu kandungan. Jakarta: YBPSP; 2009

4. Proverawati, Atikah dan Misaroh Siti. Menarche menstruasi pertama penuh makna. Yogyakarta:Nuha Medika;2009

5. Poltekkes Depkes Jakarta. Kesehatan remaja problem dan solusinya. Jakarta: Salemba Medika; 2010

6. Wibowo. Permasalah reproduksi remaja dan alternatif jalan keluarnya. Tersedia dari : http://reproduksi.co.id.67gjk/ki9ojo.jgk. 2008,

7. Ambarwati F, R..Gizi dan kesehatan reproduksi.Yogyakarta: Cakrawala Ilmu; 2012

8. Kemenkes, Kementerian KesehatanRepublik Indonesia. Riset kesehatan dasar 2010. Jakarta: Kemenkes RI;2012

9. Al-Awadhi N, Al-Kandari N, Al-HasanT, Al Murjan D, Ali S, Al-Taiar A. Ageat menarche and its relationship to bodymass index among adolescent girls in Kuwait. BMC Public Health. 2013;13:29. http://www.biomedcentral.com/1471-2458/13/29.

10. Morris DH, JonesME, Schoemaker MJ,Ashworth A, Swerdlow AJ. 2010, Determinants of age at menarche in the UK: analyses from the Breakthrough Generations Study. Br J Cancer. 103(11): 1760 - 1764 .

11. Jamaluddin. Psikologi perkembangan (masa remaja). Tersedia dari : http://remaja. co.id.6583hnfjd//;jfksd,2009

12. Karapanou O, Anastasios P. Determinants of menarche. BioMed Central Ltd. 2010 [internet]. [cited 2014.

13. Prasetyawati AE. Kesehatan ibu dan anak (KIA). Yogyakarta: Nuha Medika; 2012

14. Hartati. Hubungan faktor keluarga dengan pengetahuan menstruasi remaja putri (Studi pada siswa kelas VII SMP Negeri 2 Losari Brebes) [tesis] Semarang (Indonesia): Universitas Muhammadiyah Semarang;2009

15. Hariani, Deris AS. Hubungan asupan gizi dan status gizi terhadap kejadian menstruasi dini pada siswa SMPN 1 Kabaena Timur, Jurnal Teknologi Kesehatan, Volume 13, Nomor 2.2017 
16. Rummy Islami Z, Heryudarini, Sri Desfita. Usia menarche berhubungan dengan status gizi, konsumsi makanan dan aktivitas fisik, Jurnal Kesehatan Reproduksi,8(2), 2017, ISSN: 23548762 (electronic); ISSN: 2087-703X (print).2017

17. Soetjiningsih. Tumbuh kembang remaja dan permasalahannya, Jakarta: Sagung Seto;2008

18. Maulidiah, F. Gambaran status gizi dan genetik pada kejadian menarche di perumahan Taman Pinang RW 05 Sidoarjo. Surabaya: KTI STIKES YARSIS;2011 